\title{
Global patterns and climate drivers of water- use efficiency in terrestrial ecosystems deduced from satellite-based datasets and carbon cycle models
}

\author{
Authors: Yan Sun, Shilong Piao, Mengtian Huang, Philippe \\ Ciais, Zhenzhong Zeng, Lei Cheng, Xiran Li, Xinping \\ Zhang, Jiafu Mao, Shushi Peng, Benjamin Poulter, \\ Xiaoying Shi, Xuhui Wang, Ying-Ping Wang, and Hui Zeng
}

This is the peer reviewed version of the following article: [Sun, Yan, Shilong Piao, Mengtian Huang, Philippe Ciais, Zhenzhong Zeng, Lei Cheng, Xiran Li, Xinping Zhang, Jiafu Mao, Shushi Peng, Benjamin Poulter, Xiaoying Shi, Xuhui Wang, Ying-Ping Wang, and Hui Zeng. "Global patterns and climate drivers of water-use efficiency in terrestrial ecosystems deduced from satellite-based datasets and carbon cycle models." Global Ecology and Biogeography 25, no. 3 (March 2016): 311-323.], which has been published in final form at https://dx.doi.org/10.1111/geb.12411.

This article may be used for non-commercial purposes in accordance with Wiley Terms and Conditions for Self-Archiving.

Sun, Yan , Shilong Piao, Mengtian Huang, Philippe Ciais, Zhenzhong Zeng, Lei Cheng, Xiran Li, Xinping Zhang, Jiafu Mao, Shushi Peng, Benjamin Poulter, Xiaoying Shi, Xuhui Wang, Ying-Ping Wang, and Hui Zeng. "Global patterns and climate drivers of water-use efficiency in terrestrial ecosystems deduced from satellite-based datasets and carbon cycle models." Global Ecology and Biogeography 25, no. 3 (March 2016): 311-323. DOI: 10.1111/geb.12411. 


\title{
Global patterns and climate drivers of water-use efficiency in terrestrial ecosystems deduced from satellite-based datasets and carbon cycle models
}

Yan Sun1, Shilong Piao ${ }^{1,2,3}$, Mengtian Huang ${ }^{1}$, Philippe Ciais ${ }^{4}$, Zhenzhong Zeng ${ }^{1}$, Lei Cheng ${ }^{5}$, Xiran Li $^{1}$, Xinping Zhang $^{1}$, Jiafu $\mathrm{Mao}^{6}$, Shushi Peng ${ }^{1,4}$, Benjamin Poulter ${ }^{7}$, Xiaoying Shi ${ }^{6}$, Xuhui Wang ${ }^{1}$, Ying-Ping Wang ${ }^{8}$, and Hui Zeng $^{9}$

${ }^{1}$ Sino-French Institute for Earth System Science, College of Urban and Environmental Sciences, Peking University, Beijing 100871, China, ${ }^{2}$ Key Laboratory of Alpine Ecology and Biodiversity, Institute of Tibetan Plateau Research, Chinese Academy of Sciences, Beijing 100085, China, ${ }^{3}$ CAS Center for Excellence in Tibetan Plateau Earth Sciences, Chinese Academy of Sciences, Beijing 100085, China, ${ }^{4}$ LSCE, UMR CEA-CNRS, Bat. 709, CE, L'Orme des Merisiers, Gif-sur-Yvette F-91191, France, ${ }^{5}$ Land and Water Flagship, CSIRO, GPO Box 1666, Canberra, ACT 2601, Australia, ${ }^{6}$ Climate Change Science Institute, Environmental Sciences Division, Oak Ridge National Laboratory, Oak Ridge, TN 37831, USA, ${ }^{7}$ Institute on Ecosystems, Department of Ecology, Montana State University, Bozeman, MT 59717, USA, ${ }^{8}$ Ocean and Atmosphere Flagship, CSIRO, PMB \#1, Aspendale, Vic. 3195, Australia, ${ }^{9}$ Peking University Shenzhen Graduate School, Shenzhen 518055, China

\begin{abstract}
Aim To investigate how ecosystem water-use efficiency (WUE) varies spatially under different climate conditions, and how spatial variations in WUE differ from those of transpiration-based water-use efficiency $\left(\mathrm{WUE}_{\mathrm{t}}\right)$ and transpiration-based inherent water-use efficiency $\left(\mathrm{IWUE}_{\mathrm{t}}\right)$.

Location Global terrestrial ecosystems.

Methods We investigated spatial patterns of WUE using two datasets of gross primary productivity (GPP) and evapotranspiration (ET) and four biosphere model estimates of GPP and ET. Spatial relationships between WUE and climate variables were further explored through regression analyses.

Results Global WUE estimated by two satellite-based datasets is $1.9 \pm 0.1$ and $1.8 \pm 0.6 \mathrm{~g} \mathrm{C} \mathrm{m}^{-2} \mathrm{~mm}^{-1}$ lower than the simulations from four process-based models $\left(2.0 \pm 0.3 \mathrm{~g} \mathrm{C} \mathrm{m}^{-2} \mathrm{~mm}^{-1}\right)$ but comparable within the uncertainty of both approaches. In both satellite-based datasets and process models, precipitation is more strongly associated with spatial gradients of WUE for temperate and tropical regions, but temperature dominates north of $50^{\circ} \mathrm{N}$. WUE also increases with increasing solar radiation at high latitudes. The values of WUE from datasets and process-

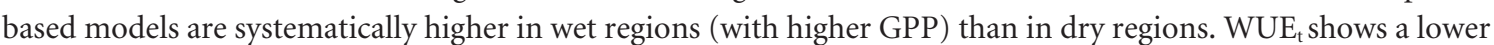
precipitation sensitivity than WUE, which is contrary to leaf- and plant-level observations. IWUE $_{t}$, the product of $\mathrm{WUE}_{\mathrm{t}}$ and water vapour deficit, is found to be rather conservative with spatially increasing precipitation, in agreement with leaf- and plant-level measurements.
\end{abstract}

Main conclusions WUE, WUE ${ }_{t}$ and $\mathrm{IWUE}_{\mathrm{t}}$ produce different spatial relation-ships with climate variables. In dry ecosystems, water losses from evaporation from bare soil, uncorrelated with productivity, tend to make WUE lower than in wetter regions. Yet canopy conductance is intrinsically efficient in those ecosystems and maintains a higher IWUE. This suggests that the responses of each component flux of evapotranspiration should be analysed separately when investigating regional gradients in WUE, its temporal variability and its trends.

\section{Keywords}

Climate drivers, inherent water-use efficiency, process-based model, satellite-based datasets, transpiration-based water-use efficiency, water-use efficiency. 


\section{INTRODUCTION}

Photosynthesis is the largest flux component of the terrestrial carbon balance (Houghton, 2007). At the same time as $\mathrm{CO}_{2}$ diffuses through leaf stomata and cell walls, with a probability of being reduced by carboxylation, water vapour diffuses out of the leaf during transpiration. Transpiration and photosynthesis are tightly coupled via leaf stomatal conductance and the various stress factors (e.g. soil drought, frost, heat) that affect leaf functioning.

At the leaf level, the ratio of instantaneous photosynthesis to transpiration defines leaf water-use efficiency (WUE). At the ecosystem scale, WUE is generally defined as the ratio of annual gross primary productivity (GPP) to annual evapotranspiration (ET). ET includes transpiration, water loss from canopy interception and evaporation from bare soil. Ecosystem WUE is regulated by canopy conductance, bare soil evaporative resistance and aerodynamic resistance. Water loss associated with ecosystem-level carbon assimilation can be divided into: (1) 'physiologically productive water' channelled through transpiration during the growing season, and (2) 'non-productive' water loss from canopy interception and evaporation from bare soil (Ponton et al., 2006; Hu et al., 2008). The partitioning of total ecosystem water loss between these two components can affect the energy balance and the coupling of the water and carbon cycles at regional and global scales (Jackson et al., 2005).

At the leaf scale, theories of optimal resource use can successfully explain the responses of WUE to various environmental factors such as increased $\mathrm{CO}_{2}$ and changes in soil water availability (Manzoni et al., 2011; Medlyn et al., 2011). Leaf WUE is observed and predicted to increase under moderate water stress, which theoretically results in decreased stomatal conductance (Manzoni et al., 2011; Niu et al., 2011). However, non-stomatal limitations, including reduced Rubisco activity and electron transport capacity, have also been found to play a significant role in modulating WUE by affecting photosynthesis (Zhou et al., 2013). As water stress becomes more severe, such internal limitations on photosynthesis dominate and reduce leaf WUE (Manzoni et al., 2011). The response of leaf WUE to water stress varies among species owing to different water-use strategies (Zhou et al., 2013), making it problematic to scale up to the plant and ecosystem level.

At the plant scale, interactions between leaf physiology, leaf area dynamics in the canopy, carbon allocation and phenology result in complex responses to changes in environmental conditions. At the ecosystem scale, water loss from soil evaporation may not respond to environmental drivers in the same way as transpiration, a further complicating factor when trying to understand WUE. Furthermore, local resource limitations (Huxman et al., 2004) and climate regimes (Still et al., 2003) leading to specific structural properties of ecosystems also determine WUE, through plant longevity, stand biomass, growingseason length and local adaptation. Difference in species composition (Niu et al., 2011), stand age and ecosystem structure may thus lead to spatially distinct patterns of WUE, even under the same mean climate conditions.
Studies of changes in ecosystem WUE along large-scale climate gradients are primarily based on site measurements and regional studies; they suggest that there are varying relationships between WUE and precipitation. Yu et al. (2008) and Lu \& Zhuang (2010) found that ecosystem WUE is higher in drier regions, consistent with leaf-scale responses, but opposite to the analysis of eddy-covariance measurements by $\mathrm{Hu}$ et al. (2008), where ecosystem WUE appeared to increase with precipitation. By defining WUE as the ratio of aboveground net primary productivity (NPP) to ET, and using long-term ecological research site data and the Moderate Resolution Imaging Spectroradiometer (MODIS) NPP satellite product, Ponce-Campos et al. (2013) found WUE to be conservative across different biomes. They also found that the response of WUE to changes in water availability varied over time, with WUE increasing to a maximum value during drought and decreasing to a minimum value in wet years. Simulations from the Dynamic Land Ecosystem Model (DLEM) by Tian et al. (2010) suggest that the relationship between WUE (NPP/ET) and annual mean precipitation is ecosystem-specific over the southern United States: in response to an increase in precipitation it is lower for wetlands and croplands and higher for forests and grasslands. Ito \& Inatomi (2012) and Tang et al. (2014) investigated the global distribution of WUE by modelling and analysis of remote sensing data, and found opposite results for dry regions (Australia and South Africa), with maximum WUE found by Tang et al. (2014) and minimum values by Ito \& Inatomi (2012).

Some of those differences may be explained by the use of different definitions of WUE, which are related to different eco-physiological processes ( $\mathrm{Hu}$ et al., 2008; Huang et al., 2015 ) or to seasonal and inter-annual variability of climate conditions (Ponce-Campos et al., 2013). Differences between the results of local studies also reflect issues of representativeness. In addition, many studies have empirically correlated WUE with precipitation gradients but ignored the confounding effects of temperature, radiation and nutrient availability (Hu et al., 2008; Yu et al., 2008; Ponce-Campos et al., 2013). Further, an analysis of WUE based on a single dataset, or on one model, is sensitive to systematic errors. Better results can be obtained by analysing the relationship between WUE and climate using different data sources and approaches. Process models incorporate eco-physiological mechanisms linking fluxes of water and $\mathrm{CO}_{2}$ on hourly to daily time steps over complete years, and thus can be used to diagnose annual WUE for comparison with observations (Huang et al., 2015).

In this study we investigate the global spatial patterns of mean ecosystem WUE using two datasets and different process-based models. Spatial drivers and limiting climatic and ecological factors controlling spatial variations in WUE have been analysed using regressions of WUE against temperature, precipitation and solar radiation. Because temperature, rainfall and radiation covary spatially, multiple regression analysis was used. In addition, two other definitions were analysed for their spatial relationship with climate, transpiration-based WUE $\left(\mathrm{WUE}_{\mathrm{t}}\right)$ and 
inherent WUE (IWUE $\mathrm{t}_{\mathrm{t}}$, that discriminate the productive uses of water from non-productive water consumption.

\section{MATERIAL AND METHODS}

\section{GPP datasets based on satellite and flux observations}

The MODIS and JUNG sets of gridded GPP data are derived from climate and satellite data and from satellite, climate and flux-tower data, respectively. MODIS GPP is estimated at a 1-km spatial resolution from a light-use efficiency model, as part of the operational MODIS algorithms (Running et al., 2004) using meteorological data from NASA Data Assimilation Office and detailed vegetation information (land cover and fraction of absorbed photosynthetically active radiation, FAPAR) derived from the MODIS satellite from 2000 to the present (Running et al., 2004; Zhao et al., 2005; Turner et al., 2006; MOD17A2, http://www.ntsg.umt.edu/, accessed 16 September 2013). JUNG GPP is another data-oriented product derived by extrapolating the flux-tower observations from 178 sites in space and time using climate data and remotely sensed FAPAR data from 1982 to 2008 (Jung et al., 2009). This latter monthly GPP product covers the period $1982-2008$ at $0.5^{\circ}$ spatial resolution.

\section{ET datasets based on satellite and flux observations}

The global distribution of ET cannot be measured directly either, and is estimated using algorithms based on meteorological and satellite data. MODIS ET is derived from the PenmanMonteith approach using the enhanced vegetation index (EVI) fields from MODIS as input (Mu et al., 2011; MOD16A2, http:// www.ntsg.umt.edu/, accessed 16 September 2013). JUNG ET is another dataset based on a model tree ensemble algorithm, which extrapolates the same flux-tower data used for the JUNG GPP but with an additional correction for energy balance closure assuming a constant Bowen ratio (Jung et al., 2010). The spatial resolution of MODIS ET and JUNG ET are same as their corresponding GPP datasets.

\section{Process-based models}

Process-based models incorporate knowledge of mechanisms, with mass, water and energy conservation principles to simulate fluxes of $\mathrm{CO}_{2}$ and water (Piao et al., 2013). Four models [the Community Land Model-4.0 (CLM); the CSIRO Atmosphere Biosphere Land Exchange-3.5 (CABLE); Lund-Potsdam-Jena, LPJ; and Organizing Carbon and Hydrology in Dynamic Ecosystems (ORCHIDEE)] were used in this study at a global resolution of $0.5^{\circ}$ (Huang et al., 2015; Piao et al., 2015). Here, we use the simulation forced with the reconstructed climate fields CRU-NCEP v.4 (http://dods.extra.cea.fr/data/p529viov/ cruncep/) and annual $\mathrm{CO}_{2}$ concentration over the period 19012012, but land cover is kept constant at its present-day state. Different physiological processes in each model lead to different simulated patterns of WUE. In particular CLM and CABLE account for the effect of nitrogen-limitation on photosynthesis. Further information about the features of each model is presented in Table S1 in the Supporting Information, and key simulation processes related to carbon and water fluxes in Table S2 and Appendix 1. More details are given by Mao et al. (2013) for CLM, Wang et al. (2011) and Zhang et al. (2013) for CABLE, Sitch et al. (2003) for LPJ and Krinner et al. (2005) for ORCHIDEE.

\section{Analyses}

GPP and ET from MODIS were re-gridded to $0.5^{\circ}$ resolution using average values across 3600 surrounding pixels of $1 \mathrm{~km}$. Monthly GPP and ET from datasets or model simulations were then summed to give annual totals. Mean annual GPP and ET were calculated for the period from 2000 to the most recent year available (different time periods are covered by each dataset, see Table S1). For both GPP and ET, grid cells with mean annual normalized difference vegetation index (NDVI; from AVHRR NDVI3g data) lower than 0.1 were discarded ( $11 \%$ of the land area).

Assuming homogeneous vegetation cover within each $0.5^{\circ}$ grid cell, the grid cell average WUE was calculated as:

$\mathrm{WUE}=\frac{\mathrm{GPP}}{\mathrm{ET}}$

with GPP in $\mathrm{g} \mathrm{C} \mathrm{m}^{-2}$ year ${ }^{-1}$ and ET in $\mathrm{mm}_{\text {year }}{ }^{-1}$. For the datasets and process models, we used only GPP and ET values produced consistently by each data-driven algorithm or model. $\mathrm{WUE}_{\mathrm{t}}$ was defined as the ratio of annual GPP to annual transpiration (T), with $\mathrm{T}$ only being available from the process models, as:

$\mathrm{WUE}_{\mathrm{t}}=\frac{\mathrm{GPP}}{\mathrm{T}}$.

Previous studies by Beer et al. (2007, 2009) suggested that 'inherent water-use efficiency' (i.e. IWUE) that accounts for the effect of the diurnal vapour pressure deficit (VPD, in $\mathrm{hPa}$ ) on WUE should provide a more robust measure of ecosystem WUE for comparing different ecosystems:

IWUE $=\frac{G P P \times V P D}{E T}$

where VPD is averaged over the growing season (defined here as the months when NDVI > 0.1) from the Global Monitoring and Assimilation Office (GMAO, http://disc.sci.gsfc.nasa.gov/daacbin/FTPSubset.pl?LOOKUPID_List=MAI3CPASM).

Mean $\mathrm{IWUE}_{\mathrm{t}}$ was calculated from the output of each processbased model as:

$\mathrm{IWUE}_{\mathrm{t}}=\frac{\mathrm{GPP} \times \mathrm{VPD}}{\mathrm{T}}$.

Annual WUE in each $0.5^{\circ}$ grid cell was projected in a twodimensional space with mean annual temperature (MAT; ranging from -20 to $30^{\circ} \mathrm{C}$ ) as the horizontal axis and mean 
annual precipitation (MAP; ranging from 0 to $2000 \mathrm{~mm}$ ) as the vertical axis, binned into intervals of $0.5^{\circ} \mathrm{C}$ MAT and $20 \mathrm{~mm}$ MAP. For all grid cells within the same MAT and MAP pixel, area-weighted averages of GPP, ET and then WUE were calculated.

We performed spatial linear regression analysis with WUE as the dependent variable and temperature, precipitation and solar radiation independent variables. The statistical significance of each regression coefficient $(P<0.05)$ was determined by $t$-statistics. Spatial climate gradients were calculated using a moving window of $4.5^{\circ} \times 4.5^{\circ}$ (81 grid cells) surrounding each $0.5^{\circ}$ grid cell.

\section{RESULTS}

\section{Global WUE}

Global WUE is estimated to be $1.8 \pm 0.6 \mathrm{~g} \mathrm{C} \mathrm{m}^{-2} \mathrm{~mm}^{-1}$ from JUNG and $1.9 \pm 0.1 \mathrm{~g} \mathrm{C} \mathrm{m}^{-2} \mathrm{~mm}^{-1}$ from MODIS products (Table 1; uncertainties \pm 1 -sigma). Mean WUE from MODIS is higher than from JUNG ( $t$-test, $P<0.05)$ in temperate zones of the Southern Hemisphere $\left(30-50^{\circ} S\right)$, but lower $(P<0.05)$ in boreal zones $\left(50-90^{\circ} \mathrm{N}\right)$. Process-based models give a global mean WUE of $2.0 \pm 0.3 \mathrm{~g} \mathrm{C} \mathrm{m}^{-2} \mathrm{~mm}^{-1}$ (range 1.7-2.3 g C $\mathrm{m}^{-2} \mathrm{~mm}^{-1}$ ), slightly larger but within the uncertainty of the datasets. The median estimate of global WUE from process models is higher than MODIS $(P<0.01)$ and JUNG $(P<0.01)$. The median absolute deviation will be used hereafter as a robust estimator of between-model differences in WUE. CLM (1.7 g C $\left.\mathrm{m}^{-2} \mathrm{~mm}^{-1}\right)$ and CABLE $\left(1.9 \mathrm{~g} \mathrm{C} \mathrm{m}^{-2} \mathrm{~mm}^{-1}\right)$ have comparable global WUE, similar to the datasets, but LPJ $\left(2.3 \mathrm{~g} \mathrm{C} \mathrm{m}^{-2} \mathrm{~mm}^{-1}\right)$ and ORCHIDEE $\left(2.1 \mathrm{~g} \mathrm{C} \mathrm{m}^{-2} \mathrm{~mm}^{-1}\right)$ give higher values. Three models (CLM, LPJ and ORCHIDEE) give systematically higher WUE than the two datasets in the boreal zone and in the temperate Southern Hemisphere (results from process-based models minus that from datasets relative difference ranging from 10 to $130 \%)$. LPJ is the main contributor to the higher WUE of models in the boreal zone; it is higher than the other three models.

\section{Spatial patterns of WUE}

The two estimates of WUE derived from datasets have large but different spatial variations (Fig. 1a,b). MODIS WUE produces a significantly higher estimate than JUNG in dryland areas $(\mathrm{MAP}<250 \mathrm{~mm})(t$-test, $P<0.05)$ with differences ranging from $1.0 \mathrm{~g} \mathrm{C} \mathrm{m}^{-2} \mathrm{~mm}^{-1}$ to more than $3.0 \mathrm{~g} \mathrm{C} \mathrm{m}^{-2} \mathrm{~mm}^{-1}$ (Fig. $1 \mathrm{~g}$ ), which can be attributed to a lower MODIS ET than JUNG ET (Fig. S4). These differences in WUE in dry areas are the main source of discrepancy in the global distribution of WUE between MODIS and JUNG. The WUE of the two datasets over mesic and humid climate regions (ranges from 1.5 to $3.0 \mathrm{~g} \mathrm{C}$ $\mathrm{m}^{-2} \mathrm{~mm}^{-1}$ ) in northern Europe, northern Eurasia, areas of tropical rain forest and eastern North America are consistently higher than in other regions $(P<0.05)$. The higher WUE occurring in mesic and humid climate regions is mainly driven by their higher GPP $(P<0.05$; Fig. S4). By contrast, the low values of WUE $\left(<1.0 \mathrm{~g} \mathrm{C} \mathrm{m}^{-2} \mathrm{~mm}^{-1}\right)$ which are found in the Qinghai Tibet Plateau, India and western North America are primarily due to the significantly higher ET than other regions $(P<0.05$; Fig. S4).

The process-based models produce broadly similar spatial patterns of WUE to the datasets (Fig. 1a-f) regardless of the large differences in GPP and ET from the four models (Fig. S4). For regions north of $50^{\circ} \mathrm{N}$, the average WUE of the processbased models is generally larger than $2.0 \mathrm{~g} \mathrm{C} \mathrm{m}^{-2} \mathrm{~mm}^{-1}$ and higher than the datasets by up to $40 \%$ (Fig. $1 \mathrm{~g}, \mathrm{~h}$ ). However, WUE north of $50^{\circ} \mathrm{N}$ varies greatly among the process-based models (Fig. 1c-f), with a standard deviation larger than $1.0 \mathrm{~g} \mathrm{C}$ $\mathrm{m}^{-2} \mathrm{~mm}^{-1}$ (range 1.0-2.0 $\mathrm{g} \mathrm{C} \mathrm{m}^{-2} \mathrm{~mm}^{-1}$; Fig. $1 \mathrm{j}$ ). In those regions, the spread between process-based models reflects low estimates from CLM $\left(<0.5 \mathrm{~g} \mathrm{C} \mathrm{m}^{-2} \mathrm{~mm}^{-1}\right)$ and high estimates

Table 1 Total water-use efficiency (WUE; g C m ${ }^{-1}$ year $\left.^{-1}\right)$ estimates for global, boreal $\left(50-90^{\circ} \mathrm{N}\right)$ and tropical $\left(30^{\circ} \mathrm{S}-30^{\circ} \mathrm{N}\right)$ areas and the temperate zones of the Northern $\left(30-50^{\circ} \mathrm{N}\right)$ and Southern $\left(30-50^{\circ} \mathrm{S}\right)$ Hemispheres $(\mathrm{NH}, \mathrm{SH})$ from two sets of observed evapotranspiration (ET) and gross primary productivity (GPP) products and four global models. For JUNG, we used 25 model tree ensembles of GPP and ET to perform Monte Carlo sampling 500 times. The median absolute deviations are used to assess the errors. For MODIS, we used a relative error of $24 \%$ in GPP (Heinsch et al., 2006) and a relative mean bias of $29 \%$ in ET (Mu et al., 2011) compared with tower observations to represent the standard deviations. Then we applied the Monte Carlo approach to assess the errors (median absolute deviations) in MODIS WUE. For process-based models, the median absolute deviations are also used to estimate the between-model differences in WUE.

\begin{tabular}{|c|c|c|c|c|c|c|c|}
\hline & JUNG & MODIS & $\begin{array}{l}\text { Process-based } \\
\text { models }\end{array}$ & CLM & CABLE & LPJ & ORCHIDEE \\
\hline Global & $1.9 \pm 0.1$ & $1.8 \pm 0.6$ & $2.0 \pm 0.3$ & 1.9 & 1.7 & 2.3 & 2.1 \\
\hline Boreal & $2.0 \pm 0.2$ & $1.6 \pm 0.4$ & $2.2 \pm 0.9$ & 2.2 & 1.9 & 3.7 & 2.3 \\
\hline NH temperate & $1.7 \pm 0.2$ & $1.7 \pm 0.3$ & $1.9 \pm 0.4$ & 1.7 & 1.7 & 2.3 & 2.1 \\
\hline SH temperate & $1.6 \pm 0.2$ & $1.8 \pm 0.8$ & $2.0 \pm 0.2$ & 2.0 & 2.0 & 1.8 & 2.1 \\
\hline Tropical & $1.9 \pm 0.2$ & $2.2 \pm 0.4$ & $1.9 \pm 0.4$ & 1.4 & 1.6 & 2.0 & 2.1 \\
\hline
\end{tabular}


(a) MODIS

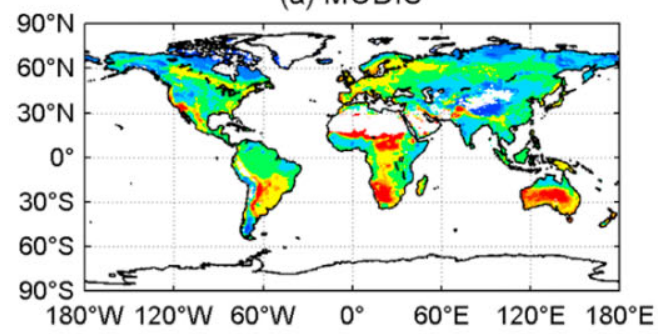

(c) CLM

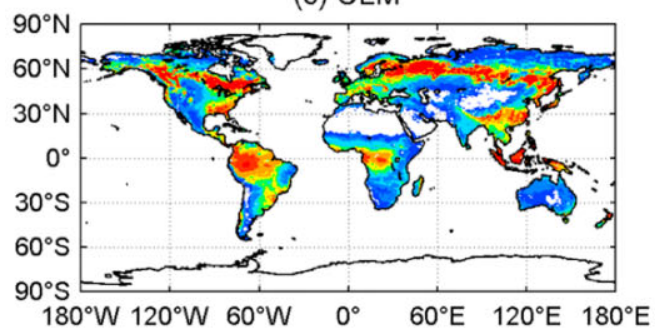

(e) LPJ

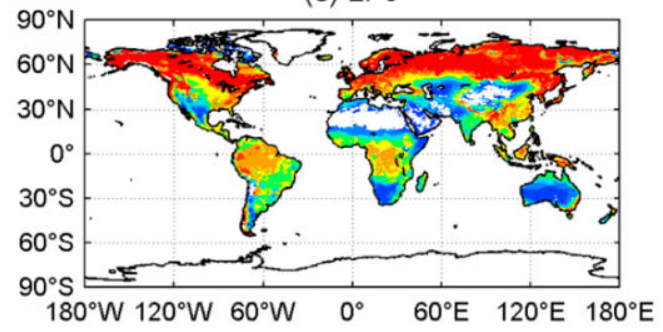

(g) Data-driven WUE

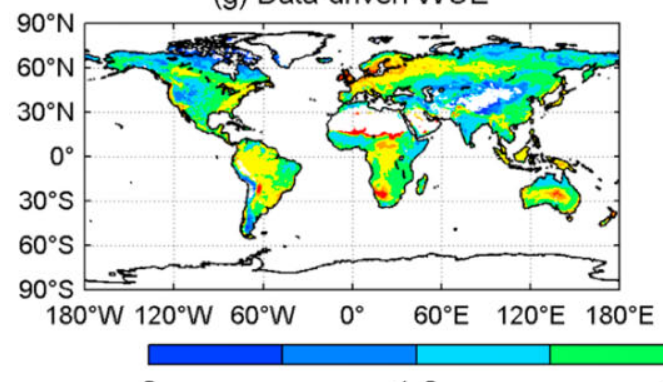

(i)

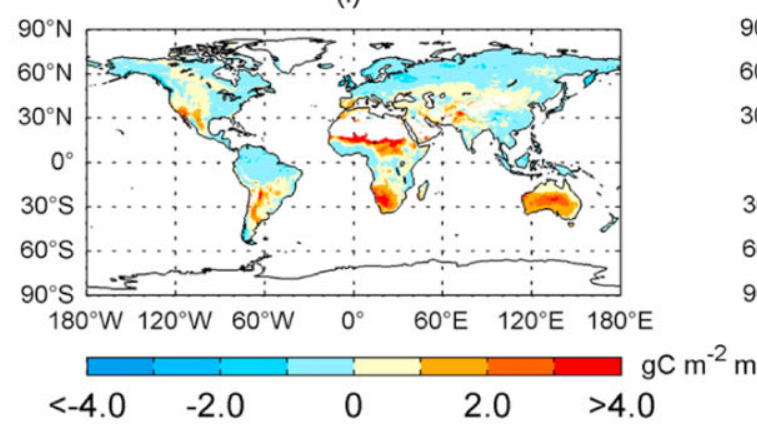

(b) JUNG

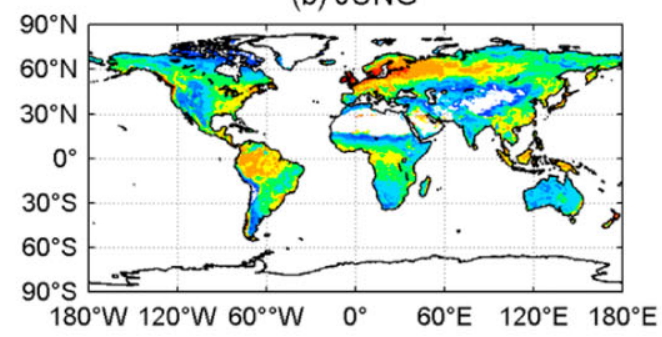

(d) CABLE

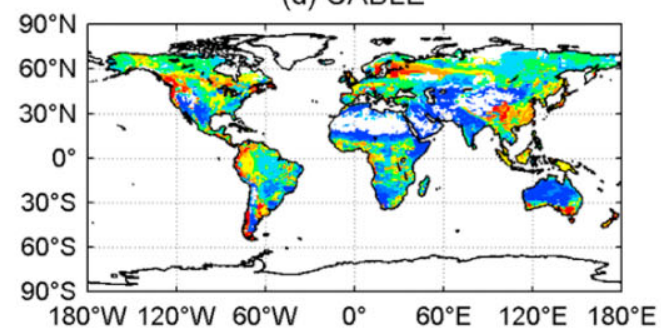

(f) ORCHIDEE

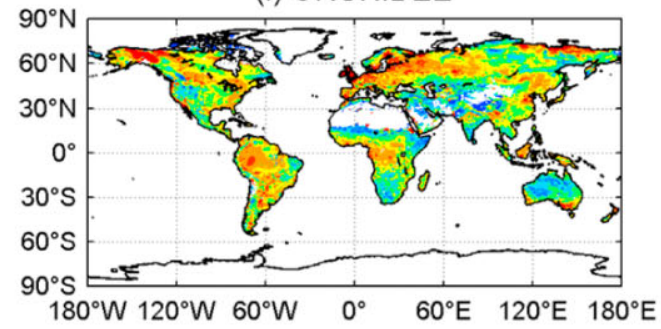

(h) Process-model WUE

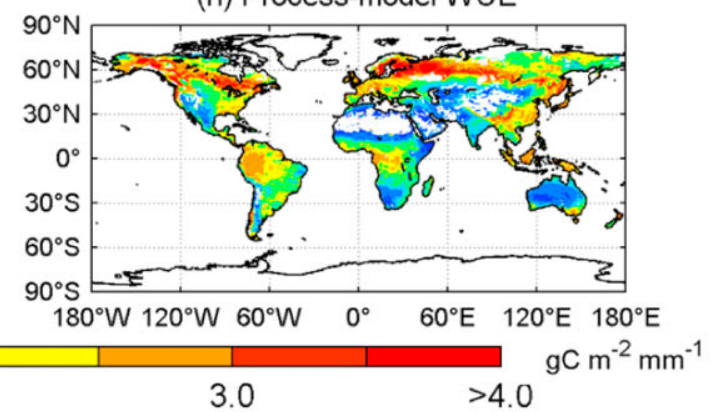

(j)

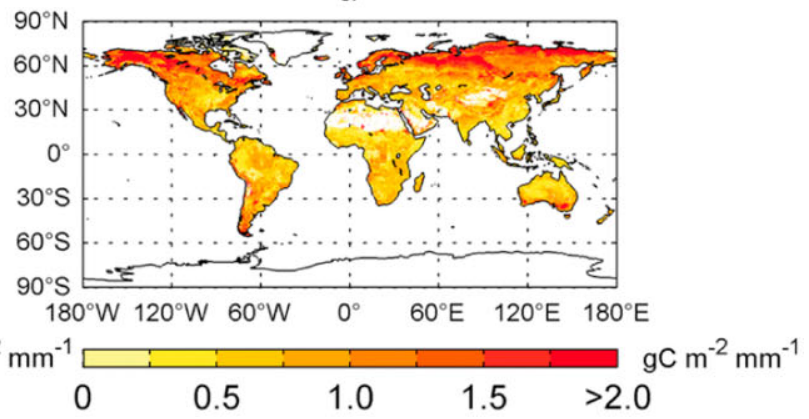

Figure 1 Global spatial patterns of land water-use efficiency (WUE) derived from (a), (b) two datasets of gross primary productivity (GPP) and evapotranspiration (ET) (MODIS and JUNG) and (c)-(f) process-based models CLM, CABLE, LPJ and ORCHIDEE, averaged from 2000 to the most recent year available (see Table S1). Panel (g) shows the mean WUE estimated by the GPP and ET datasets, and (h) shows the simulated median WUE across the four models. Values of mean annual normalized difference vegetation index below 0.1 have been screened out. Panel (i) indicates the differences between the two dataset-based WUE distributions (MODIS minus JUNG), and panel (j) the median absolute deviation of WUE among four process-based models. MODIS GPP and ET are derived from MODIS satellite data, while JUNG GPP and ET are derived by extrapolating the flux-tower observations using climate data and remotely sensed fraction of absorbed photosynthetically active radiation (Jung et al., 2009). 
from LPJ (> $3.5 \mathrm{~g} \mathrm{C} \mathrm{m}^{-2} \mathrm{~mm}^{-1}$ ) (Fig. 1c-f), which produce a relatively lower ET than other models $(P<0.05)$.

\section{Variation of the sensitivities of WUE to MAP and MAT}

Spatial variations of WUE with MAT and MAP are quite similar between the datasets and process-based models when they are compared in MAT-MAP phase space (Fig. 2). Globally, WUE using both approaches appears to reach a maximum for an 'optimal' range of MAP, which depends upon MAT. WUE from datasets is maximum in regions with MAP $>1300 \mathrm{~mm}$ and MAT in the range $7-10{ }^{\circ} \mathrm{C}$ (Fig. 2a). WUE from process-based models is maximum in regions with MAP $>500 \mathrm{~mm}$ and MAT in the range of $0-6{ }^{\circ} \mathrm{C}$ (Fig. 2b).

Variations of WUE along gradients of MAP or MAT, measured by precipitation sensitivity $\left(S_{\mathrm{P}}\right)$ and temperature sensitivity $\left(S_{\mathrm{T}}\right)$, using the two approaches are quite different, as shown by the insets of Fig. 2. Dataset-based WUE have positive values of $S_{\mathrm{T}}$ in arid regions with MAP less than $200 \mathrm{~mm}$ and negative values of $S_{\mathrm{T}}$ in wet regions where MAP is over $1000 \mathrm{~mm}$ (Fig. 2a). Process models exhibit negative values of $S_{\mathrm{T}}$ across almost the entire MAP range (Fig. 2b). $S_{\mathrm{P}}$ estimated from datasets remains positive even in very cold regions $\left(\mathrm{MAT}<0{ }^{\circ} \mathrm{C}\right.$ ), while process-model $S_{\mathrm{P}}$ becomes negative when MAT is lower than $0{ }^{\circ} \mathrm{C} . S_{\mathrm{P}}$ estimated from models decreases with MAT when MAT is lower than $10^{\circ} \mathrm{C}$, then increases with MAT in the interval $10-15^{\circ} \mathrm{C}$, and decreases with MAT when MAT is higher than $15^{\circ} \mathrm{C}$ (Fig. 2a). In contrast, $S_{\mathrm{P}}$ estimated from process-based models increases with MAT in the interval -10 to $10^{\circ} \mathrm{C}$, then remains almost constant when MAT is higher than $10^{\circ} \mathrm{C}$ (Fig. 2b). Compared with WUE, WUE ${ }_{t}-S_{\mathrm{P}}$ shows similar variations with MAT: $S_{\mathrm{P}}$ increases with temperature in the MAT interval $3-10^{\circ} \mathrm{C}$ and then remains almost constant when MAT is higher than $10^{\circ} \mathrm{C}$ (Fig. 3a, bottom panel). However, the positive $\mathrm{WUE}_{\mathrm{t}}-S_{\mathrm{P}}$ appears to be much lower (Fig. 3a, bottom panel), and the negative $\mathrm{WUE}_{\mathrm{t}}-S_{\mathrm{T}}$ is much higher (Fig. 3a, left panel) than that for WUE. IWUE has a distribution in the MAT-MAP climate space which looks similar to that of $\mathrm{WUE}_{\mathrm{t}}$ (Fig. 3b). But IWUE $\mathrm{t}_{\mathrm{t}}$ gradients appear to be mainly controlled by MAT rather than MAP.

The distribution of spatial sensitivity of WUE to climate variables (multiple regression) shows similar WUE-MAP and WUE-MAT relationships to those diagnosed from MAP-MAT phase space. Positive spatial $S_{\mathrm{P}}$ mainly occurs in dry regions south of $50^{\circ} \mathrm{N}$ such as the western United States, central Asia and dry areas of north-east Asia (Fig. S2), while negative $S_{\mathrm{P}}$ is mainly found at high latitudes $\left(>60^{\circ} \mathrm{N} ; P<0.05\right)$. Positive $S_{\mathrm{T}}$ prevails in regions north of $50^{\circ} \mathrm{N}$, as well as in the Qinghai Tibet Plateau and South Africa $(P<0.05)$. On the contrary, negative $S_{\mathrm{T}}$ values occur over most tropical and temperate regions except for Qinghai Tibet Plateau and South Africa (Fig. S2b). In terms of the spatial sensitivity of WUE to short-wave downward radiation $\left(S_{\mathrm{R}}\right)$, both dataset-based and process-model WUE show that positive values of $S_{\mathrm{R}}$ dominate high latitudes (Fig. S2c) and negative $S_{\mathrm{R}}$ values over low $\left(30^{\circ} \mathrm{S}-30^{\circ} \mathrm{N}\right)$ and mid-latitude (30$60^{\circ} \mathrm{N}$ ) regions (Fig. S2c).

\section{DISCUSSION}

\section{The main differences between dataset-based and model-based WUE}

The two distributions of WUE estimates based on datasets are similar in terms of global mean values, but show different spatial patterns, especially in regions with low ET (tropical dry areas). Differences in WUE between MODIS and JUNG are primarily due to their systematic differences in ET (Fig. S4). ET produced by MODIS is lower than JUNG in dry areas and higher in humid areas (Fig. S4). These differences in ET lead to differences in mean WUE, as well as in spatial gradients of WUE. Uncertainties in ET datasets can have a number of causes, such as different climate forcing data or the model used (Vinukollu et al., 2011). Even though the differences between two dataset-based WUE are mainly explained by differences in ET, both MODIS and JUNG also show different GPP (Fig. S4). MODIS produces a systematically lower GPP than JUNG in tropical regions (Fig. S4), except during June-August (see the comparison made by Frankenberg et al., 2011), which partly contributes to the differences in WUE. For MODIS, the EVI used in the GPP algorithm may not capture reduced photosynthesis during the dry season in tropical forests (see Lee et al., 2013b for Amazonia) and may produce negatively biased values during the wet season because of unfiltered clouds (Frankenberg et al., 2011). For JUNG GPP, systematic errors in boreal and tropical regions (both savannas and forests) have been suggested by Frankenberg et al. (2011), who compared JUNG GPP with the latitudinal distribution of chlorophyll- $a$ fluorescence data. These errors were possibly because of the sparse sampling of the flux-tower network in those areas. These uncertainties explain the difference in WUE observed between MODIS and JUNG, in particular for tropical regions (Fig. 1).

Compared with the two datasets, WUE from process-based models is generally higher (mainly because process-modelsimulated GPP is generall higher than that of the two datasets, while ET is not; Table 1 and Figs 1, S1 \& S4). We note that relatively higher GPP is generally simulated along with the relatively higher ET by process-based models, and vice versa, which leads to smaller differences in WUE between models (Figs 1 \& S4). However, the differences in model-based GPP mainly give rise to the different WUE for most regions (Fig. S4). But for boreal regions, LPJ produced a relatively lower ET than the other three models, and thus led to an extraordinarily high WUE. The between-model differences in WUE can be attributed to different model structures and parameters. Table S2 and Appendix 1 summarize the key simulation processes relating to carbon and water fluxes in process-based models. Including or not nutrient limitation of GPP, using different soil moisture stress functions for GPP (e.g., Sulman et al., 2012), as well as different prescribed soil depths, root profiles and soil water holding capacities, can change the ratio between GPP and ET in each model, thus 
Figure 2 Distribution of mean water-use efficiency (WUE) in the mean annual temperature (MAT)-mean annual precipitation (MAP) domain: (a) datasets, (b) process-based models. The bottom insets show the MAP sensitivity across the MAT range. Black lines in insets refer to the absolute changes of WUE (slope calculated from simple linear regression between WUE and MAP under the same MAT interval) along the MAP gradient. Red/grey lines represent the relative changes (calculated as the absolute slope value divided by the mean WUE of all MAP zones with same small range of MAT) of WUE. The grey scale in the bottom and left insets indicates uncertainties among two datasets and four models results, the darkest zones representing the largest uncertainty. Similarly, the left insets show the MAT sensitivity across the MAP range.

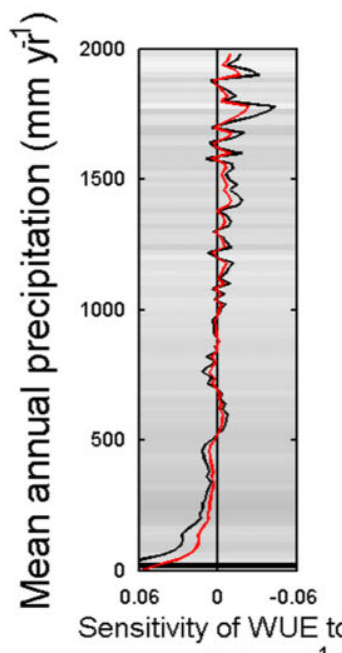

(a) Data-driven WUE

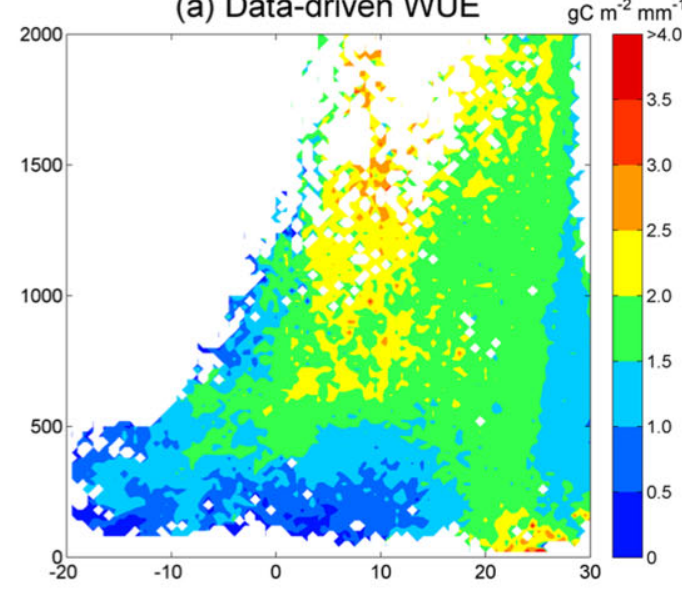
temperature $\left(\mathrm{gC} \mathrm{mm}^{-1}\right.$

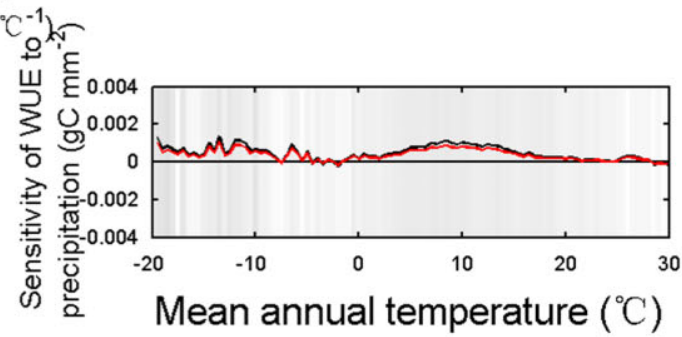

호을
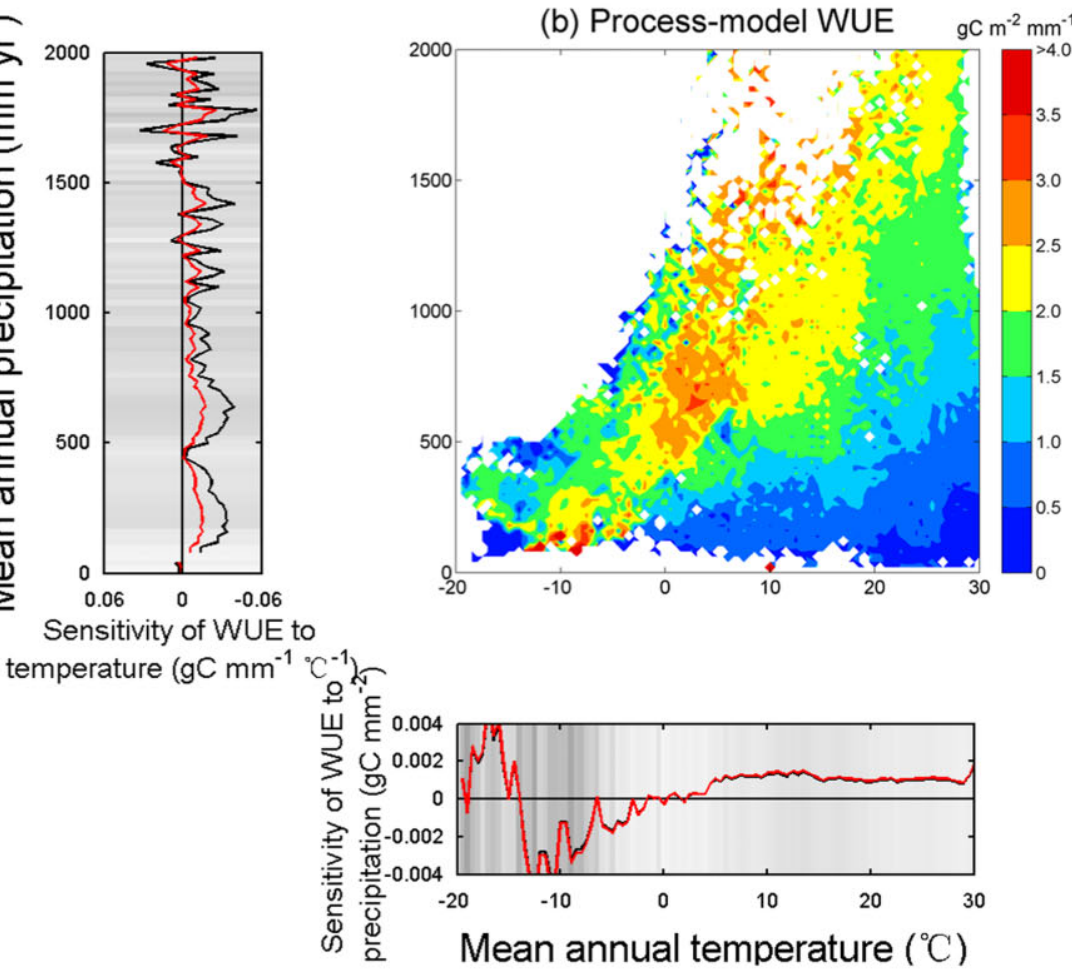


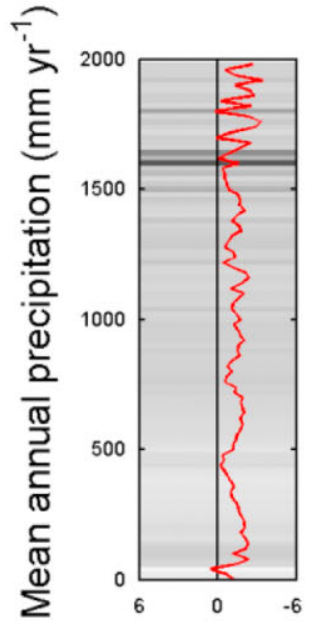

Sensitivity of WUEt to temperature $\left(\%{ }^{\circ} \mathrm{C}^{-1}\right)$

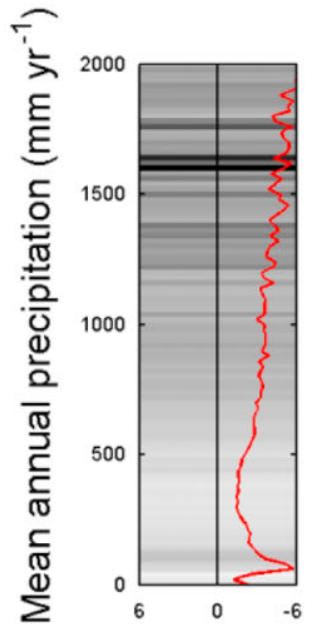

Sensitivity of IWUEt to temperature $\left(\%{ }^{\circ} \mathrm{C}^{-1}\right)$
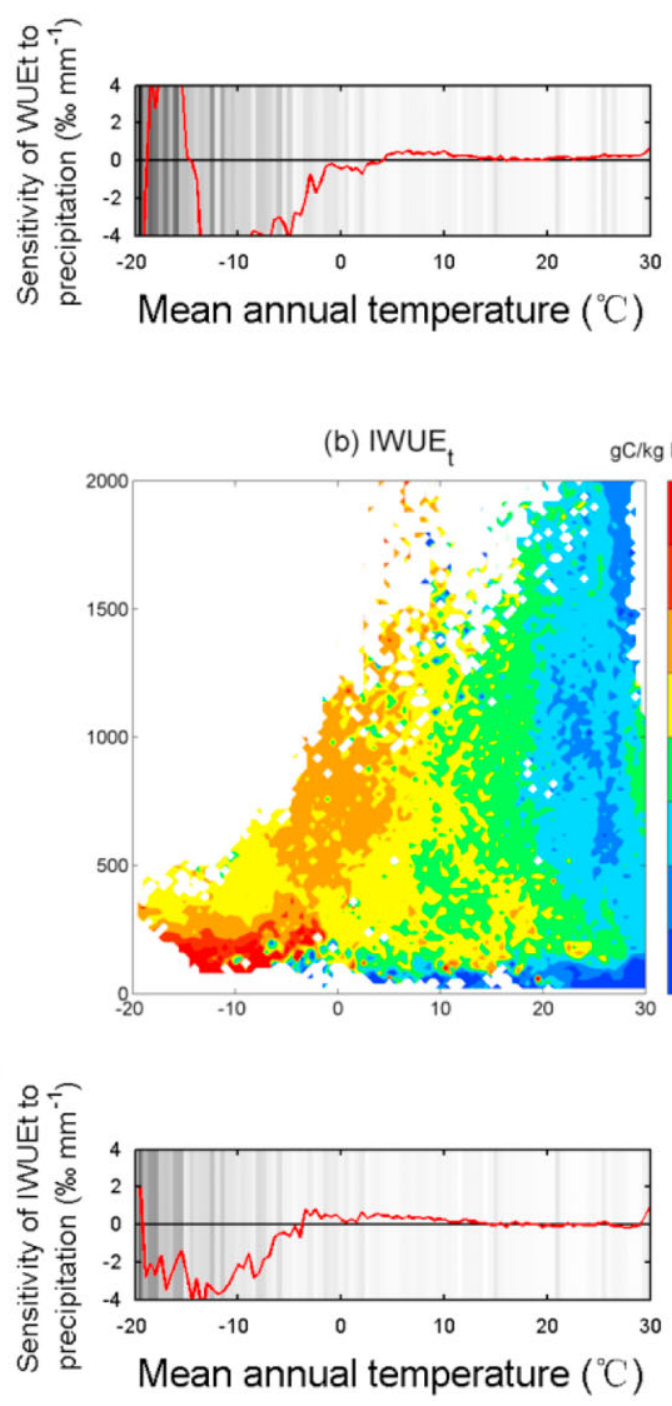

(a) WUE

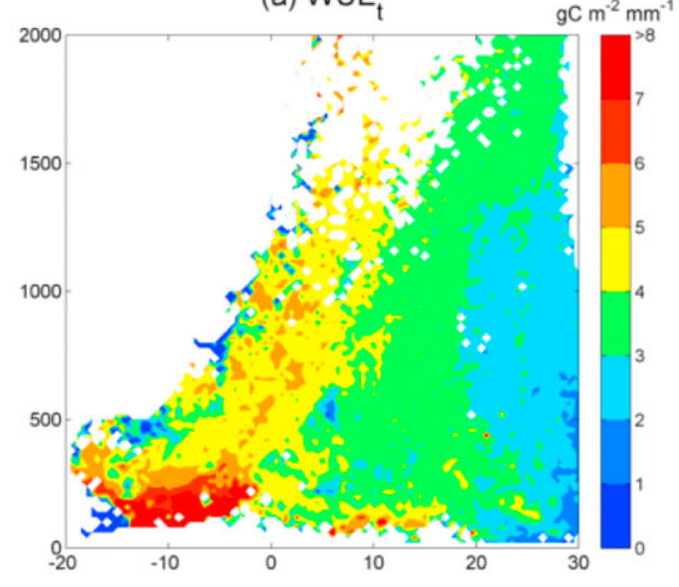

(b) IWUE

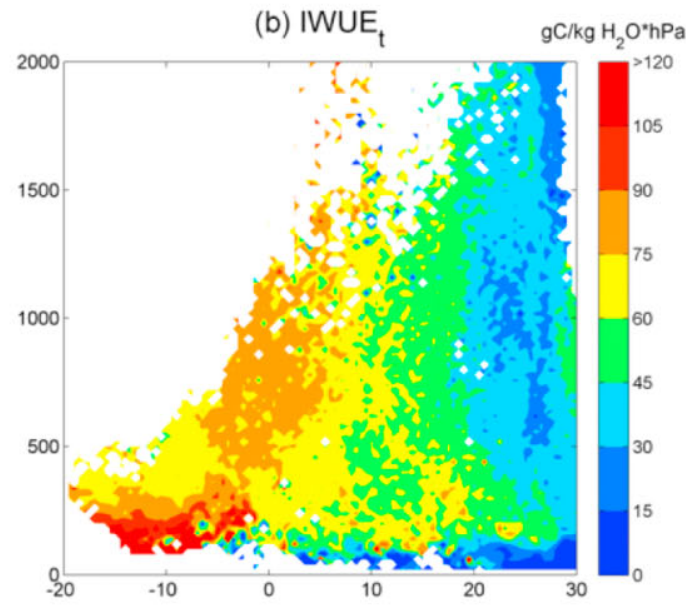
(c)
Figure 3 Distribution of (a) mean transpiration-based water-use efficiency $\left(\mathrm{WUE}_{\mathrm{t}}\right.$ ) and (b) transpiration-based inherent water-use efficiency ( IWUE $_{t}$ ) in the MAT-MAP domain from

process-based models. The bottom insets show the MAP sensitivity (red/grey lines) across the MAT range and the grey scale indicates uncertainties among four model results, in which the darkest zones represent largest uncertainty. Similarly, the left insets show the MAT sensitivity across the MAP range. causing between-model differences in WUE. Follow-up studies to understand differences in WUE simulated by different process models could diagnose their response to separate variables (e.g. change in nitrogen availability) through factorial simulations under a coordinated model inter-comparison framework (e.g. Ms TMIP).

Regulation of plant productivity (Cleveland et al., 2013) from nutrient availability also has an impact on WUE gradients. 
Fisher et al. (2012) used an 'inverse approach' to infer regions with nutrient limitation from the negative deviations of NDVI from a maximum NDVI-ET slope, which is close to a maximum envelope for WUE. They found that the majority of terrestrial ecosystems are subject to some degree of nutrient limitation. Most previous studies of the responses of WUE to nitrogen addition were plant-scale field experiments. The results of these studies suggest that WUE significantly increases with increasing nitrogen supply (Livingston et al., 1999; Ripullone et al., 2004). At the ecosystem scale, nitrogen limitation has been considered to decrease vegetation productivity and ET compared with optimal values by reducing photosynthetic capacity (Wang et al., 2010) and canopy conductance (Lee et al., 2013a). Yan et al. (2014) suggested that the effect of nitrogen addition on vegetation productivity (i.e. NPP) was larger than on ET, thus leading to increased WUE in nitrogen-rich soils. Although some models have accounted for full nitrogen cycles, it is still not known whether they can reproduce such asymmetric impacts of nitrogen availability on GPP and ET, and thus the impacts on WUE. Future model inter-comparison projects including scenarios that drive models solely with changes in nitrogen supply should help to assess this issue better. In our study, the CABLE and CLM models which integrate interactions between carbon and nitrogen produce a lower WUE than other models, especially in boreal regions, possibly reflecting nitrogen limitation.

Lastly, land-cover inconsistencies also cause differences in WUE between different models; land cover was kept constant in the process models analysed, and the land-cover map used in models differs from that used in the two datasets. Land-use and land-cover change can thus also explain differences between model- and satellite-derived estimates of WUE in regions with significant land-use change. Note that secondary forest in the tropics has shallower roots than primary forest, which implies differences in WUE due to land-use change.

\section{Spatial patterns of WUE and the decoupling of GPP and ET}

With the exception of MODIS WUE, the spatial distributions of WUE estimated from different approaches consistently show higher values in wetter regions (Fig. 1a-f). For mid- and lowlatitude ecosystems with seasonal water limitation, spatial gradients in WUE are found to be strongly associated with precipitation gradients (Fig. 4a). For those regions, the sensitivity of GPP to precipitation $\left(S_{\mathrm{P}, \mathrm{GPP}}\right)$ is higher than the sensitivity of ET to precipitation ( $S_{\mathrm{P}, \mathrm{ET}}$; Fig. S5). Increasing annual precipitation would mitigate water limitation and thus sustain plant growth more efficiently. This means more efficient ecosystem WUE in wetter regions (Huxman et al., 2004). The positive sensitivity of WUE to precipitation gradually declines from arid and semi-arid regions towards mesic and humid regions. For humid regions, such as northern Europe and tropical rain forest, $S_{\mathrm{P}}$ approaches zero ( $S_{\mathrm{P}, \mathrm{GPP}}$ is comparable to $S_{\mathrm{P}, \mathrm{ET}}$; Fig. S5) because: (1) increasing runoff may deplete the nutrients available for plant growth through leaching, causing negative feedback on GPP (Huxman et al., 2004); and (2) cloudiness covarying with precipitation is also reported to decrease short-wave downward radiation, which co-limits GPP in wet and cloudy regions (Scanlon \& Albertson, 2004). In the context of long-term adaptation of GPP in areas with abundant precipitation, plants with higher resource-use efficiency for nutrients and radiation than for water have a competitive advantage in long-term selection (Huxman et al., 2004). A difference that could explain the spatially inconsistent responses of the sensitivity of WUE to precipitation between the two approaches is illustrated in Fig. 4(a). Without considering nutrient limitation, models predict that WUE is larger where precipitation is higher; therefore WUE is found to be positively correlated with precipitation, even in rain forest (Fig. S2a,b). Conversely, at high latitudes dataset-based and process-model WUE are both co-limited by temperature and radiation (Fig. 4b,c), and air temperature and incoming solar radiation are positively correlated with ecosystem productivity (Piao et al., 2007), hence leading to a higher WUE in warmer areas. Additionally, one study with the DLEM found the highest WUE to be in forests and wetland, followed by grassland and cropland ecosystems (Tian et al., 2010). Thus, spatial and elevational distributions of different biomes also influence the spatial patterns of WUE. It should also be noted that observations of chlorophyll- $a$ fluorescence from GOSAT (Frankenberg et al., 2011) suggest that both MODIS and JUNG underestimate GPP for savannas in the tropics (for which no flux-tower observations were available in JUNG) and may overestimate GPP in tropical forest and boreal regions. So it is possible that GPP biases in MODIS and JUNG lead to low-biased WUE for savannas and high-biased WUE in boreal regions and tropical forests.

\section{Differences between WUE defined from ET and from transpiration}

Most current models and observations indicate that transpiration dominates the terrestrial water flux emitted to the atmosphere (Lawrence et al., 2007; Jasechko et al., 2013). Based on this, previous studies have used ET, expecting it to be close to T, to calculate ecosystem WUE. Figure 2 indicates that WUE increases with precipitation along climate gradients, which seems to contradict evidence from WUE observations at leaf and plant scales that water stress reduces T per unit of GPP. Note that the contribution of soil evaporation to total ET is larger in arid and semi-arid ecosystems due to the sparse vegetation coverage (Hu et al., 2008) and low humidity. High rates of soil evaporation act to decrease WUE. However, in this study, process-model WUE $\mathrm{E}_{\mathrm{t}}$ defined by GPP/T is still higher with larger MAP (Fig. 3a), suggesting that the lower WUE in dry regions compared with wet regions cannot be explained just by an increased fraction of soil evaporation to ET. The positive $\mathrm{WUE}_{\mathrm{t}}-S_{\mathrm{P}}$ can be explained as follows. On the one hand, plant transpiration in dry ecosystems can support the evaporative demand with deep root distributions, implying that the $\mathrm{WUE}_{\mathrm{t}}$ of deep-rooted drier systems could be lower than in shallowrooted summer-dry mesic ecosystems. On the other hand, canopy-scale studies (Baldocchi, 1994; Hu et al., 2008) also show that $\mathrm{WUE}_{\mathrm{t}}$ at the canopy scale is mainly controlled by photo- 
(a)

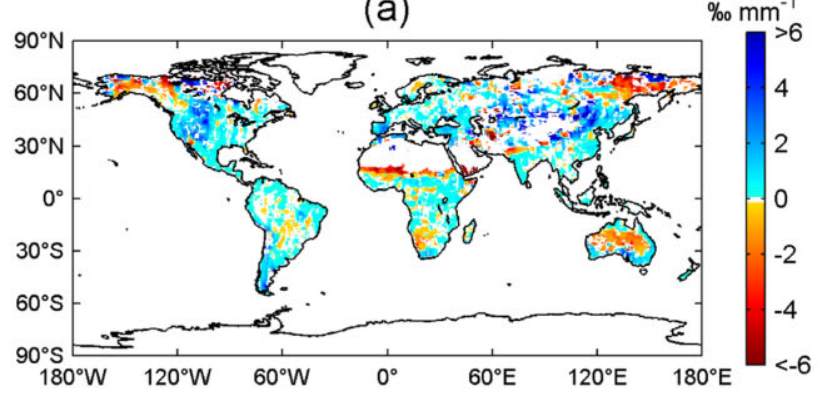

(c)

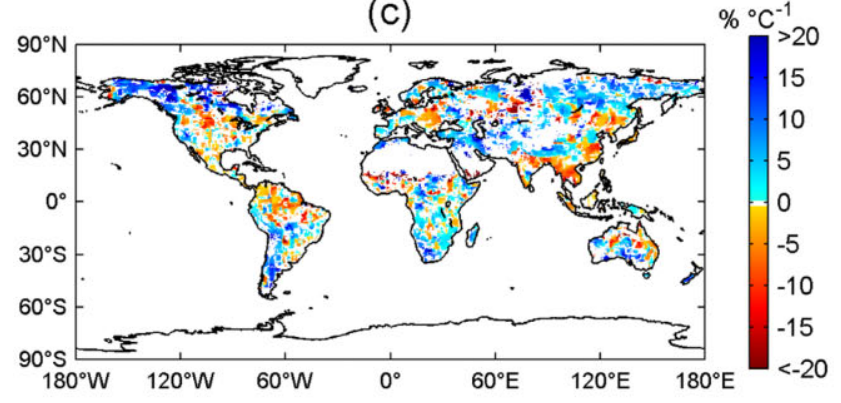

(e)

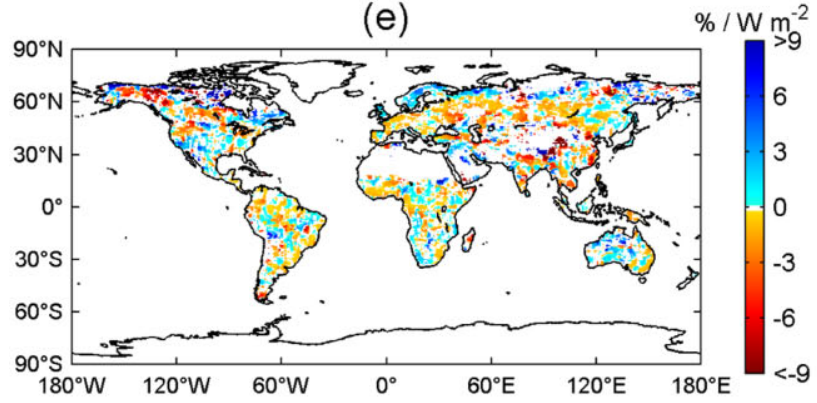

(b)

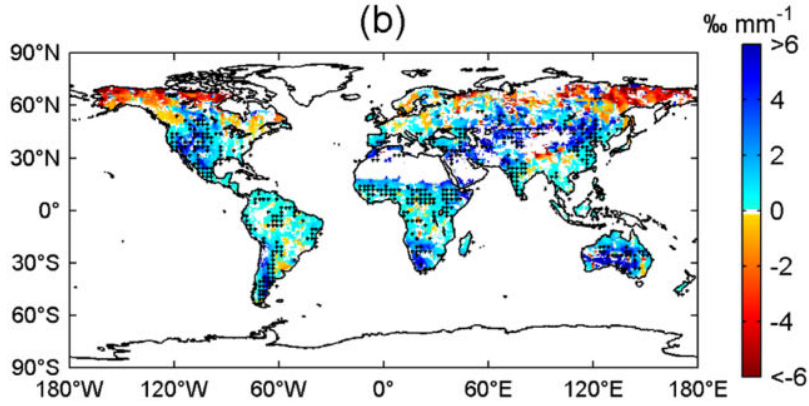

(d)

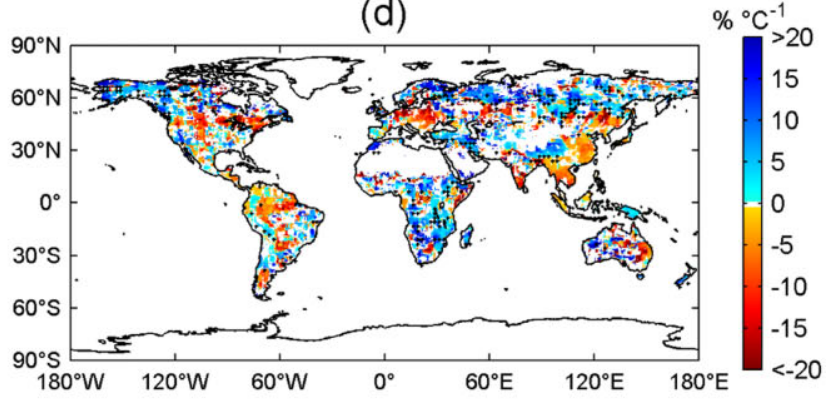

(f)

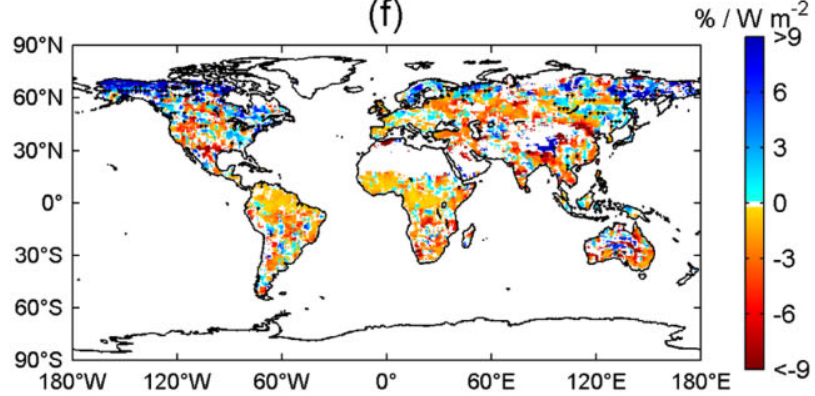

Figure 4 Spatial sensitivity of water-use efficiency (WUE) to: (a), (b) precipitation, (c), (d) temperature, and (e), (f) solar radiation, based on datasets (left-hand column) and process models (right-hand column). Black points in the right-hand column indicate regions where three of four models show the same sign of sensitivity. Only statistically significant $(P<0.05)$ correlations are shown.

synthesis rather than by T. Denser canopies of vegetation growing in humid conditions have both effective light interception and high light-use efficiency (Hu et al., 2008). In those ecosystems, photosynthesis scaled to the canopy thickness benefits from the fraction of diffuse radiation which tends to make GPP higher per unit of water loss. However, the positive modelled $\mathrm{WUE}_{\mathrm{t}}-S_{\mathrm{P}}$ is much lower than that for WUE, indicating a weak dependence of plant WUE on precipitation in dry regions.

\section{Effects of VPD, differences between WUE and inherent WUE}

Increased VPD at the leaf surface has been found to reduce leaf WUE (Linderson et al., 2012). Similar responses have also been observed at canopy or ecosystem scales (Ponton et al., 2006; Niu et al., 2011; Linderson et al., 2012). However, while taking into account the effect of VPD, WUE is found to be positively correlated with VPD (Beer et al., 2009; Linderson et al., 2012). In our study, model-based IWUE $_{\mathrm{t}}$ also shows quite a different spatial relationship with MAP compared with WUE, with slightly negative $S_{\mathrm{p}}$ values in warm dry regions (Fig. $3 \mathrm{~b}$ ). This finding agrees qualitatively with most leaf-scale WUE measurements of higher values under dry conditions, with drought-tolerant species showing physiological mechanisms to resist drought (Zhou et al., 2013). In arid regions, more water vapour is lost to the atmosphere through evaporation from bare soil (Hu et al., 2008), and transpiration is also partly driven by a high VPD. This high evaporative and high VPD-driven transpiration water loss, partly decoupled from vegetation productivity, lead to a lower WUE in dry areas than in wetter areas in process-models

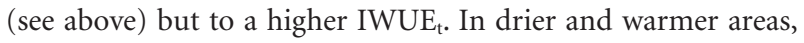
C4 grasses (Still et al., 2003) have a more efficient photosynthesis pathway that allows fast carbon assimilation with high intrinsic WUE. This process is implicitly included in datasets and in process-models that have specific $\mathrm{C} 4$ vegetation types, and can explain the negative $\mathrm{IWUE}_{t}-S_{\mathrm{P}}$ in warm dry areas. In wet regions with high vegetation coverage and low VPD, most of the water consumption is closely bound up with productivity, and hence leads to a higher WUE. We also calculated IWUE (equation 3) from datasets to compare with process-models. A lower $S_{\mathrm{P}}$ is 
consistently found for IWUE compared with WUE for the two approaches (Fig. S3a). IWUE derived from process-models (Fig. S3b) shows generally similar spatial patterns to those from datasets, except over dry areas with MAP $<200 \mathrm{~mm}$. But this response of IWUE to precipitation is different from that of IWUE $_{\mathrm{t}}$ in process models (Fig. 3b), with IWUE $_{\mathrm{t}}$ showing a weakly negative $S_{\mathrm{P}}$ across the whole MAT range, suggesting an important influence of evaporation from bare soil on IWUE. Consistent IWUE-MAP relationships derived from datasets and process-models suggests that defining WUE on the basis of transpiration $\left(\mathrm{WUE}_{\mathrm{t}}, \mathrm{IWUE}_{\mathrm{t}}\right.$ ) tends to reduce the discrepancy between the two approaches.

\section{CONCLUSIONS}

Higher ecosystem WUE was diagnosed from datasets and from process-based models with increasing MAP, which is contrary to leaf- and plant-level observations of higher WUE under dry conditions. Our analysis, based on three definitions of WUE (WUE, WUE $\mathrm{t}_{\mathrm{t}}$ and $\mathrm{IWUE}_{\mathrm{t}}$ ), suggests that different mechanisms underlie the response of WUE to spatially increasing precipitation. In arid ecosystems, water losses uncorrelated with vegetation productivity lead to a lower WUE, whereas their control of canopy conductance is intrinsically efficient at maintaining a higher IWUE $\mathrm{t}_{\mathrm{t}}$. Furthermore, WUE, WUE $\mathrm{t}_{\mathrm{t}}$ and $\mathrm{IWUE}_{\mathrm{t}}$ respond differently to climate variables, so we recommend that when comparing WUE trends each water loss component should be considered separately.

\section{ACKNOWLEDGEMENTS}

We sincerely acknowledge the contribution of the editor and two referees, whose constructive suggestions have significantly improved this manuscript from its earlier version. This study was supported by the National Natural Science Foundation of China (41530528), National Basic Research Program of China (2013CB956303), the 111 Project (B14001), and National Youth Top-notch Talent Support Program in China. Jiafu Mao and Xiaoying Shi's time and the CLM simulation are supported by the US Department of Energy (DOE), Office of Science, Biological and Environmental Research. Oak Ridge National Laboratory is managed by UT-BATTELLE for the DOE under contract DE-AC05-00OR22725.

\section{REFERENCES}

Baldocchi, D. (1994) A comparative study of mass and energy exchange rates over a closed $\mathrm{C}_{3}$ (wheat) and an open $\mathrm{C}_{4}$ (corn) crop: II. $\mathrm{CO}_{2}$ exchange and water use efficiency. Agricultural and Forest Meteorology, 67, 291-321.

Beer, C., Reichstein, M., Ciais, P., Farquhar, G.D. \& Papale, D. (2007) Mean annual GPP of Europe derived from its water balance. Geophysical Research Letters, 34, L05401.

Beer, C., Ciais, P., Reichstein, M., Baldocchi, D., Law, B.E., Papale, D., Soussana, J.F., Ammann, C., Buchmann, N., Frank, D., Gianelle, D., Janssens, I.A., Knohl, A., Köstner, B., Moors,
E., Roupsard, O., Verbeeck, H., Vesala, T., Williams, C.A. \& Wohlfahrt, G. (2009) Temporal and among-site variability of inherent water use efficiency at the ecosystem level. Global Biogeochemical Cycles, 23, GB2018.

Cleveland, C.C., Houlton, B.Z., Smith, W.K., Marklein, A.R., Reed, S.C., Parton, W., Del Grosso, S.J. \& Running, S.W. (2013) Patterns of new versus recycled primary production in the terrestrial biosphere. Proceedings of the National Academy of Sciences USA, 110, 12733-12737.

Fisher, J.B., Badgley, G. \& Blyth, E. (2012) Global nutrient limitation in terrestrial vegetation. Global Biogeochemical Cycles, 26, GB3007.

Frankenberg, C., Fisher, J.B., Worden, J., Badgley, G., Saatchi, S.S., Lee, J.-E., Toon, G.C., Butz, A., Jung, M., Kuze, A. \& Yokota, T. (2011) New global observations of the terrestrial carbon cycle from GOSAT: patterns of plant fluorescence with gross primary productivity. Geophysical Research Letters, 38, L17706.

Heinsch, F.A., Zhao, M., Running, S.W., Kimball, J.S., Nemani, R.R., Davis, K.J., Bolstad, P.V., Cook, B.D., Desai, A.R. \& Ricciuto, D.M. (2006) Evaluation of remote sensing based terrestrial productivity from MODIS using regional tower eddy flux network observations. IEEE Transactions on Geoscience and Remote Sensing, 44, 1908-1925.

Houghton, R.A. (2007) Balancing the global carbon budget. Annual Review of Earth and Planetary Sciences, 35, 313-347.

Hu, Z., Yu, G., Fu, Y., Sun, X., Li, Y., Shi, P., Wang, Y. \& Zheng, Z. (2008) Effects of vegetation control on ecosystem water use efficiency within and among four grassland ecosystems in China. Global Change Biology, 14, 1609-1619.

Huang, M.T., Piao, S.L., Sun, Y., Ciais, P., Cheng, L., Mao, J.F., Poulter, B., Shi, X.Y., Zeng, Z.Z. \& Wang, Y.P. (2015) Change in terrestrial ecosystem water-use efficiency over the last three decades. Global Change Biology, 21, 2366-2378.

Huxman, T.E., Smith, M.D., Fay, P.A., Knapp, A.K., Shaw, M.R., Loik, M.E., Smith, S.D., Tissue, D.T., Zak, J.C. \& Weltzin, J.F. (2004) Convergence across biomes to a common rain-use efficiency. Nature, 429, 651-654.

Ito, A. \& Inatomi, M. (2012) Water-use efficiency of the terrestrial biosphere: a model analysis focusing on interactions between the global carbon and water cycles. Journal of Hydrometeorology, 13, 681-694.

Jackson, R.B., Jobbágy, E.G., Avissar, R., Roy, S.B., Barrett, D.J., Cook, C.W., Farley, K.A., Le Maitre, D.C., McCarl, B.A. \& Murray, B.C. (2005) Trading water for carbon with biological carbon sequestration. Science, 310, 1944-1947.

Jasechko, S., Sharp, Z.D., Gibson, J.J., Birks, S.J., Yi, Y. \& Fawcett, P.J. (2013) Terrestrial water fluxes dominated by transpiration. Nature, 496, 347-350.

Jung, M., Reichstein, M. \& Bondeau, A. (2009) Towards global empirical upscaling of FLUXNET eddy covariance observations: validation of a model tree ensemble approach using a biosphere model. Biogeosciences, 6, 2001-2013.

Jung, M., Reichstein, M., Ciais, P. et al. (2010) Recent decline in the global land evapotranspiration trend due to limited moisture supply. Nature, 467, 951-954. 
Krinner, G., Viovy, N., de Noblet-Ducoudré, N., Ogée, J., Polcher, J., Friedlingstein, P., Ciais, P., Sitch, S. \& Prentice, I.C. (2005) A dynamic global vegetation model for studies of the coupled atmosphere-biosphere system. Global Biogeochemical Cycles, 19, GB1015.

Lawrence, D.M., Thornton, P.E., Oleson, K.W. \& Bonan, G.B. (2007) The partitioning of evapotranspiration into transpiration, soil evaporation, and canopy evaporation in a GCM: impacts on land-atmosphere interaction. Journal of Hydrometeorology, 8, 862-880.

Lee, E., Felzer, B.S. \& Kothavala, Z. (2013a) Effects of nitrogen limitation on hydrological processes in CLM4-CN. Journal of Advances in Modeling Earth Systems, 5, 741-754.

Lee, J.-E., Frankenberg, C., van der Tol, C., Berry, J.A., Guanter, L., Boyce, C.K., Fisher, J.B., Morrow, E., Worden, J.R. \& Asefi, S. (2013b) Forest productivity and water stress in Amazonia: observations from GOSAT chlorophyll fluorescence. Proceedings of the Royal Society B: Biological Sciences, 280, 20130171.

Linderson, M.-L., Mikkelsen, T.N., Ibrom, A., Lindroth, A., Ro-Poulsen, H. \& Pilegaard, K. (2012) Up-scaling of water use efficiency from leaf to canopy as based on leaf gas exchange relationships and the modeled in-canopy light distribution. Agricultural and Forest Meteorology, 152, 201-211.

Livingston, N., Guy, R., Sun, Z. \& Ethier, G. (1999) The effects of nitrogen stress on the stable carbon isotope composition, productivity and water use efficiency of white spruce (Picea glauca (Moench) Voss) seedlings. Plant, Cell and Environment, 22, 281-289.

Lu, X. \& Zhuang, Q. (2010) Evaluating evapotranspiration and water-use efficiency of terrestrial ecosystems in the conterminous United States using MODIS and AmeriFlux data. Remote Sensing of Environment, 114, 1924-1939.

Manzoni, S., Vico, G., Katul, G., Fay, P.A., Polley, W., Palmroth, S. \& Porporato, A. (2011) Optimizing stomatal conductance for maximum carbon gain under water stress: a meta-analysis across plant functional types and climates. Functional Ecology, 25, 456-467.

Mao, J., Shi, X., Thornton, P.E., Hoffman, F.M., Zhu, Z. \& Myneni, R.B. (2013) Global latitudinal-asymmetric vegetation growth trends and their driving mechanisms: 1982-2009. Remote Sensing, 5, 1484-1497.

Medlyn, B.E., Duursma, R.A., Eamus, D., Ellsworth, D.S., Prentice, I.C., Barton, C.V., Crous, K.Y., de Angelis, P., Freeman, M. \& Wingate, L. (2011) Reconciling the optimal and empirical approaches to modelling stomatal conductance. Global Change Biology, 17, 2134-2144.

Mu, Q., Zhao, M. \& Running, S.W. (2011) Improvements to a MODIS global terrestrial evapotranspiration algorithm. Remote Sensing of Environment, 115, 1781-1800.

Niu, S., Xing, X., Zhang, Z., Xia, J., Zhou, X., Song, B., Li, L. \& Wan, S. (2011) Water-use efficiency in response to climate change: from leaf to ecosystem in a temperate steppe. Global Change Biology, 17, 1073-1082.

Piao, S.L., Friedlingstein, P., Ciais, P., Viovy, N. \& Demarty, J. (2007) Growing season extension and its impact on terrestrial carbon cycle in the Northern Hemisphere over the past 2 decades. Global Biogeochemical Cycles, 21, GB3018.

Piao, S.L., Sitch, S., Ciais, P. et al. (2013) Evaluation of terrestrial carbon cycle models for their response to climate variability and to CO2 trends. Global Change Biology, 19, 21172132.

Piao, S.L., Yin, G.D., Tan, J.G., Cheng, L., Huang, M.T., Li, Y., Liu, R.G., Mao, J.F., Myneni, R.B., Peng, S.S., Poulter, B., Shi, X.Y., Xiao, Z.Q., Zeng, N., Zeng, Z.Z. \& Wang, Y.P. (2015) Detection and attribution of vegetation greening trend in China over the last 30 years. Global Change Biology, 21, 1601-1609.

Ponce-Campos, G.E., Moran, M.S., Huete, A., Zhang, Y., Bresloff, C., Huxman, T.E., Eamus, D., Bosch, D.D., Buda, A.R. \& Gunter, S.A. (2013) Ecosystem resilience despite large-scale altered hydroclimatic conditions. Nature, 494, 349-352.

Ponton, S., Flanagan, L.B., Alstad, K.P., Johnson, B.G., Morgenstern, K., Kljun, N., Black, T.A. \& Barr, A.G. (2006) Comparison of ecosystem water-use efficiency among Douglas-fir forest, aspen forest and grassland using eddy covariance and carbon isotope techniques. Global Change Biology, 12, 294-310.

Ripullone, F., Lauteri, M., Grassi, G., Amato, M. \& Borghetti, M. (2004) Variation in nitrogen supply changes water-use efficiency of Pseudotsuga menziesii and Populus $\times$ euroamericana; a comparison of three approaches to determine water-use efficiency. Tree Physiology, 24, 671-679.

Running, S.W., Nemani, R.R., Heinsch, F.A., Zhao, M.S., Reeves, M. \& Hashimoto, H. (2004) A continuous satellite-derived measure of global terrestrial primary production. BioScience, 54, 547-560.

Scanlon, T.M. \& Albertson, J.D. (2004) Canopy scale measurements of $\mathrm{CO}_{2}$ and water vapor exchange along a precipitation gradient in southern Africa. Global Change Biology, 10, 329341.

Sitch, S., Smith, B., Prentice, I.C., Arneth, A., Bondeau, A., Cramer, W., Kaplan, J., Levis, S., Lucht, W. \& Sykes, M.T. (2003) Evaluation of ecosystem dynamics, plant geography and terrestrial carbon cycling in the LPJ dynamic global vegetation model. Global Change Biology, 9, 161-185.

Still, C.J., Berry, J.A., Collatz, G.J. \& DeFries, R.S. (2003) Global distribution of C3 and C4 vegetation: carbon cycle implications. Global Biogeochemical Cycles, 17, 6-1-6-14.

Sulman, B.N., Desai, A.R., Schroeder, N.M., Ricciuto, D., Barr, A., Richardson, A.D., Flanagan, L.B., Lafleur, P.M., Tian, H., Chen, G., Grant, R.F., Poulter, B., Verbeeck, H., Ciais, P., Ringeval, B., Baker, I.T., Schaefer, K., Luo, Y. \& Weng, E. (2012) Impact of hydrological variations on modeling of peatland $\mathrm{CO}_{2}$ fluxes: results from the North American Carbon Program site synthesis. Journal of Geophysical Research. Biogeosciences, 117, G01031.

Tang, X., Li, H., Desai, A.R., Nagy, Z., Luo, J., Kolb, T.E., Olioso, A., Xu, X., Yao, L. \& Kutsch, W. (2014) How is water-use efficiency of terrestrial ecosystems distributed and changing on Earth? Scientific Reports, 4, art. no. 7483.

Tian, H., Chen, G., Liu, M., Zhang, C., Sun, G., Lu, C., Xu, X., Ren, W., Pan, S. \& Chappelka, A. (2010) Model estimates of 
net primary productivity, evapotranspiration, and water use efficiency in the terrestrial ecosystems of the southern United States during 1895-2007. Forest Ecology and Management, 259, 1311-1327.

Turner, D.P., Ritts, W.D., Cohen, W.B., Gower, S.T., Running, S.W., Zhao, M.S., Costa, M.H., Kirschbaum, A.A., Ham, J.M., Saleska, S.R. \& Ahl, D.E. (2006) Evaluation of MODIS NPP and GPP products across multiple biomes. Remote Sensing of Environment, 102, 282-292.

Vinukollu, R.K., Wood, E.F., Ferguson, C.R. \& Fisher, J.B. (2011) Global estimates of evapotranspiration for climate studies using multi-sensor remote sensing data: evaluation of three process-based approaches. Remote Sensing of Environment, $115,801-823$.

Wang, Y., Law, R. \& Pak, B. (2010) A global model of carbon, nitrogen and phosphorus cycles for the terrestrial biosphere. Biogeosciences, 7, 2261-2282.

Wang, Y., Kowalczyk, E., Leuning, R., Abramowitz, G., Raupach, M.R., Pak, B., van Gorsel, E. \& Luhar, A. (2011) Diagnosing errors in a land surface model (CABLE) in the time and frequency domains. Journal of Geophysical Research. Biogeosciences, 116, G01034.

Yan, J., Zhang, D., Liu, J. \& Zhou, G. (2014) Interactions between $\mathrm{CO}_{2}$ enhancement and $\mathrm{N}$ addition on net primary productivity and water-use efficiency in a mesocosm with multiple subtropical tree species. Global Change Biology, 20, 2230-2239.

Yu, G., Song, X., Wang, Q., Liu, Y., Guan, D., Yan, J., Sun, X., Zhang, L. \& Wen, X. (2008) Water-use efficiency of forest ecosystems in eastern China and its relations to climatic variables. New Phytologist, 177, 927-937.

Zhang, Q., Pitman, A., Wang, Y., Dai, Y. \& Lawrence, P. (2013) The impact of nitrogen and phosphorous limitation on the estimated terrestrial carbon balance and warming of land use change over the last 156 yr. Earth System Dynamics, 4, 333 345.

Zhao, M., Heinsch, F.A., Nemani, R.R. \& Running, S.W. (2005) Improvements of the MODIS terrestrial gross and net primary production global data set. Remote Sensing of Environment, 95, 164-176.

Zhou, S., Duursma, R.A., Medlyn, B.E., Kelly, J.W. \& Prentice, I.C. (2013) How should we model plant responses to drought? An analysis of stomatal and non-stomatal responses to water stress. Agricultural and Forest Meteorology, 182, 204-214.

\section{SUPPORTING INFORMATION}

Additional supporting information may be found in the online version of this article at the publisher's web-site.

Figure S1 Comparisons of gross primary productivity and evapotranspiration between products from datasets and outputs simulated by process models.

Figure S2 Spatial sensitivity of water-use efficiency to precipitation, temperature and solar radiation.

Figure S3 Distribution of mean inherent water-use efficiency in the mean annual temperature-mean annual precipitation domain.
Figure S4 Global patterns of gross primary productivity (g C $\mathrm{m}^{-2}$ year $^{-1}$ ) and evapotranspiration $\left(\mathrm{mm} \mathrm{year}^{-1}\right)$.

Figure S5 Spatial sensitivity of gross primary productivity and evapotranspiration to mean annual precipitation.

Figure S6 Spatial sensitivity of gross primary productivity and evapotranspiration to mean annual temperature.

Figure S7 Spatial sensitivity of gross primary productivity and evapotranspiration to short-wave downward radiation.

Table S1 Information on the four process models used in this study.

Table S2 Key simulation processes related with carbon and water fluxes in the four models.

Editor: Josep Peñuelas

\section{APPENDIX 1 SOURCES OF DATA AND MODELS USED IN THIS STUDY}

Ball, J.T., Woodrow, I.E. \& Berry, J.A. (1987) A model predicting stomatal conductance and its contribution to the control of photosynthesis under different environmental conditions. Progress in photosynthesis research (ed. by J. Biggins), pp. 221-224. Springer, Dordrecht.

Ball, T. \& Berry, J. (1982) Ci/Cs ratio: a basis for predicting stomatal control of photosynthesis. Carnegie Institution of Washington Yearbook-, 81, 88-92.

Collatz, G.J., Ribas-Carbo, M. \& Berry, J. (1992) Coupled photosynthesis-stomatal conductance model for leaves of C4 plants. Functional Plant Biology, 19, 519-538.

Ducoudré, N.I., Laval, K. \& Perrier, A. (1993) SECHIBA, a new set of parameterizations of the Ducoudré, N.I., Laval, K. \& Perrier, A. (1993) SECHIBA, a new set of parameterizations of the
hydrologic exchanges at the land-atmosphere interface within the LMD atmospheric general circulation model. Journal of Climate, 6, 248-273.

Farquhar, G., von Caemmerer, S.V. \& Berry, J. (1980) A biochemical model of photosynthetic $\mathrm{CO}_{2}$ assimilation in leaves of $\mathrm{C} 3$ species. Planta, $149,78-90$.

Federer, C.A. (1982) Transpirational supply and demand: plant, soil, and atmospheric effects evaluated by simulation. Water Resources Research, 18, 355-362.

Garratt, J. (1992) Extreme maximum land surface temperatures. Journal of Applied Meteorology, 31, 1096-1105.

Gerten, D., Schaphoff, S., Haberlandt, U., Lucht, W. \& Sitch, S. (2004) Terrestrial vegetation and water balance - hydrological evaluation of a dynamic global vegetation model. Journal of Hydrology, 286, 249-270.

Haxeltine, A. \& Prentice, I.C. (1996) BIOME3: an equilibrium terrestrial biosphere model based on ecophysiological constraints, resource availability, and competition among plant functional types. Global Biogeochemical Cycles, 10, 693-709.

Huntingford, C. \& Monteith, J. (1998) The behaviour of a mixed-layer model of the convective boundary layer coupled to a big leaf model of surface energy partitioning. Boundary-Layer Meteorology, 88, 87-101.

Jackson, R., Canadell, J., Ehleringer, J., Mooney, H., Sala, O. \& Schulze, E. (1996) A global analysis of root distributions for terrestrial biomes. Oecologia, 108, 389-411.

Leuning, R. (1995) A critical appraisal of a combined stomatal-photosynthesis model for C3 plants. Plant, Cell and Environment, 18, 339-355.

Oleson, K.W., Lawrence, D.M., Gordon, B., Flanner, M.G., Kluzek, E., Peter, J., Levis, S., Swenson, S.C., Thornton, E. \& Feddema, J. (2010) Technical description of version 4.0 of the Community Land Model (CLM). NCAR Technical Note TN-478+STR. National Center for Atmospheric Research, Boulder, CO.

Parton, W.J., Hartman, M., Ojima, D. \& Schimel, D. (1998) DAYCENT and its land surface submodel: description and testing. Global and Planetary Change, 19, 35-48.

Shi, X., Mao, J., Thornton, P.E. \& Huang, M. (2013) Spatiotemporal patterns of evapotranspiration in response to multiple environmental factors simulated by the Community Land Model. Environmental Research Letters, 8, 024012.

Wang, Y., Kowalczyk, E., Leuning, R., Abramowitz, G., Raupach, M.R., Pak, B., van Gorsel, E. \& Luhar, A. (2011) Diagnosing errors in a land surface model (CABLE) in the time and frequency domains. Journal of Geophysical Research. Biogeosciences, 116, G01034.

Wang, Y.-P. \& Leuning, R. (1998) A two-leaf model for canopy conductance, photosynthesis and partitioning of available energy I: model description and comparison with a multi-layered model. Agricultural and Forest Meteorology, 91, 89-111. 